\title{
Acute Oxalate Nephropathy Due to Bilimbi Poisoning: A Case Report
}

Rajat Das Gupta, ${ }^{1}$ Muradul Islam, ${ }^{1}$ Debashis Datta, ${ }^{1}$ Suranjan Kumar. ${ }^{1}$

\begin{abstract}
Background: The concentrated juice made from Averrhoa bilimbi is rich in oxalic acid. It can cause acute oxalate nephropathy by blocking the tubules with calcium oxalate crystals. Case: An elderly woman was admitted to the hospital with a history of swelling of the legs, facial puffiness, and abdominal distention. Her biochemical study revealed features of acute renal failure. She gave history of taking half liter of bilimbi juice. Renal biopsy confirmed it was a case of acute oxalic nephropathy, which made it the second case of acute oxalic nephropathy due to ingestion of bilimbi juice ever reported from Bangladesh. Conclusion: It is not safe to consume high oxalate-containing fruits in large quantities.
\end{abstract}

Keywords: Averrhoa bilimbi; Acute Kidney Injury; Hemodialysis (Source: MeSH, NLM).

\section{Introduction}

About the Authors: Rajat Das Gupta, Debashis Datta, and Suranjan Kumar recently graduated from Dhaka Medical College and are currently working at Dhaka Medical College Hospital as Intern Doctors. Muradul Islam is current ly working as Registrar at the Department of Surgery, Dhaka Medical College Hospital.

Submission: Apr 21, 201

Acceptance: Oct 17, 2015

Publication: Feb 05, 2016

Process: Peer-reviewed

\section{The Case}

Acute kidney injury is caused by some plant toxins. ${ }^{1}$ The toxic plants are known to be used in therapeutic, cosmetic and even suicidal purposes. ${ }^{2,3}$ Averrhoa bilimbi, which is commonly known as bilimbi, belongs to the family of the 0xalidaceae. Widely cultivated in the tropical regions, bilimbi fruits are used in the production of vinegar, wine, pickles and in the preparation of some Indian dishes. Cough, mumps, rheumatic diseases, pimples and scurvy are often treated with bilimbi fruits. ${ }^{4}$ High amounts of oxalate make it a nephrotoxic agent. ${ }^{5}$ Acute oxalate nephropathy after ingestion of $A$. bilimbi juice is uncommon. ${ }^{6}$ Few cases have been reported in India. ${ }^{5,6}$

This article discusses a case of acute oxalate nephropathy after ingestion of $A$. bilimbi juice in a patient admitted in a hospital in Dhaka, Bangladesh. Written informed consent was taken from both the patient and her husband to discuss her case in the form of published case report.

A sixty-two-year-old female was admitted to a private hospital in Mid Badda, Dhaka with a history of bilateral leg swelling, facial puffiness, abdominal distention, abdominal pain, nausea and vomiting for two days. At first she had fever, associated with chills and rigor. Subsequently she developed the above mentioned symptoms. There was no history of oliguria, hematuria, or frothing of urine, dysuria, shortness of breath, or haemoptysis. She was a known case of systemic hypertension for last 15 years, and she was taking amlodipine $5 \mathrm{mg}$ and atenolol $50 \mathrm{mg}$ once daily as antihypertensive medication since her diagnosis. She took aterovastatin 1omg for hypercholesterolemia. She had no significant past surgical and family history. All of her family members are in good health. There was no relevant psychosocial history of the patient. On query, she informed that she consumed $500 \mathrm{ml}$ of homemade juice made

Key Points:
- Acute renal failure can occur after ingestion of bilimbi juice due to the
deposition of calcium oxalate crystals within the renal tubules, which
blocks the tubules.
- High intake of bilimbi juice in concentrated form can lead to acute
renal failure and should be avoided.
- Efforts are required to raise the public awareness regarding the dan-
ger of consuming bilimbi juice in high quantity in South East Asian
countries, where A. bilimbi juice is used as a remedy of hypertension,
diabetes, and dyslipidemia.

from A. bilimbi fruits two days back. The oxalate content of the fruit was $26.6 \mathrm{mg}$ per $100 \mathrm{~g}$ of the fruit, which was analyzed by spectrophotometry method in the laboratory of the hospital.

On examination of the patient, she was conscious, alert and co-operative. Bilateral periorbital puffiness was present. Bipedal pitting oedema was present. Her blood pressure was 200/110 mmHg. Abdominal examination revealed abdominal distension, but evidence of ascites was absent. The rest of the examination was within normal limits.

Her serum creatinine was $6.8 \mathrm{mg} / \mathrm{dl}$ (normal range: 0.7-1.3 $\mathrm{mg} / \mathrm{dl}$ ), which suggested severe renal failure. Microalbuminuria and plenty of oxalate crystals were found in her urine. A 24-hour urinary oxalate test returned negative results. Hematological investigations were within normal limits (Table 1). Ultrasound of her abdomen revealed right kidney size of 10.2 $\mathrm{cm} \times 4.9 \mathrm{~cm}$ and left kidney size of $9.8 \mathrm{~cm} \times 4.7 \mathrm{~cm}$ without any evidence of calculi or hydronephrosis. Echogenicity and corticomedullary differentiation were normal. As differential diagnosis, we considered heart failure. But echocardiography revealed no abnormality.

Her blood pressure was controlled by nifedipine ( $20 \mathrm{mg}$ tablets twice a day) and hydralazine hydrochloride (25 $\mathrm{mg}$ tablets four

'Dhaka Medical College and Hospital, Dhaka, Bangladesh.

\author{
Correspondence: \\ Rajat Das Gupta. \\ Address: Dhaka Medical College and Hospital, Secretariate Rd, Dhaka 1000, Bangladesh. \\ Email: rajat89.dasgupta@gmail.com
}


Table 1. Laboratory Findings of the Patient

\begin{tabular}{|c|c|c|}
\hline Category & Laboratory Test & Result (Normal Values) \\
\hline \multirow[t]{3}{*}{ Hematological Findings } & Haemoglobin & $9.2 \mathrm{mg} / \mathrm{dl}(12.1-15.1 \mathrm{~g} / \mathrm{dl})$ \\
\hline & Red Blood Cells & $320,000 / \mathrm{cm}^{3}\left(390,000-520,000 / \mathrm{cm}^{3}\right)$ \\
\hline & Total Count of White Blood Cells & $7,400 / \mathrm{cm}^{3}\left(4,000-11,000 / \mathrm{cm}^{3}\right)$ \\
\hline \multirow{6}{*}{$\begin{array}{l}\text { Differential Count of } \\
\text { White Blood Cells }\end{array}$} & Neutrophils & $56 \%(40-80 \%)$ \\
\hline & Lymphocytes & $32 \%(20-40 \%)$ \\
\hline & Monocytes & $8 \%(2-10 \%)$ \\
\hline & Basophils & $4 \%(<1-2 \%)$ \\
\hline & Eosinophils & $0 \%(1-6 \%)$ \\
\hline & Platelets & $175,000 / \mathrm{cm}^{3}\left(150,000-400,000 / \mathrm{cm}^{3}\right)$ \\
\hline \multirow[t]{4}{*}{ Lipid Profile (mg/dl) } & Total Cholesterol & $195(200-239)$ \\
\hline & High-Density Lipoprotein & $50(35-60)$ \\
\hline & Low-Density Lipoprotein & $98(130-159)$ \\
\hline & Triglyceride & $130(150-199)$ \\
\hline \multirow{3}{*}{$\begin{array}{l}\text { Serum Electrolytes } \\
\text { During Admission } \\
(\mathrm{mmol} / \mathrm{l})\end{array}$} & Sodium & $132(135-145)$ \\
\hline & Potassium & $4.2(3.5-5)$ \\
\hline & Chloride & $104(95-105)$ \\
\hline \multirow{3}{*}{$\begin{array}{l}\text { Serum Electrolytes Du- } \\
\text { ring Discharge }(\mathrm{mmol} / \mathrm{l})\end{array}$} & Sodium & $141(135-145)$ \\
\hline & Potassium & $3.7(3.5-5)$ \\
\hline & Chloride & $107(95-105)$ \\
\hline \multirow{4}{*}{$\begin{array}{l}\text { Serum Creatinine } \\
(\mathrm{mg} / \mathrm{dl})\end{array}$} & During Admission & $6.8(0.7-1.3)$ \\
\hline & After 1 st session of Hemodialysis & $5.2(0.7-1.3)$ \\
\hline & After 2nd session of Hemodialysis & $3.1(0.7-1.3)$ \\
\hline & During discharge & $0.8(0.7-1.3)$ \\
\hline \multirow[t]{3}{*}{ Urinary Findings } & Pus Cells & 10-15/HPF (2-5/HPF) \\
\hline & Oxalate Crystals & Plenty (Occasionally) \\
\hline & Red Blood Cells & $8-10 / \mathrm{HPF}(\leq 2 / \mathrm{HPF})$ \\
\hline
\end{tabular}

HPF=high-power field. absorption of oxalate and/or increased production of oxalate. ${ }^{6}$ In this reported case, this is due to secondary hyperoxaluria and A. bilimbi was the primary causal agent.

In our study the patient took bilimbi juice due to hypercholesterolemia. Similar findings were found by Nair et al. ${ }^{5}$ Bilimbi juice is advocated in hyperlipidemia, hypertension, and diabetes in many parts of the world. ${ }^{9}$ It has been found in rats that bilimbi fruit has a cholesterol-lowering effect. ${ }^{10}$ In comparison to metformin and distilled water, bilimbi extracts lower blood glucose by $50 \%$ and blood triglyceride by $130 \% .5$ It is also reported that bilimbi extract increases high-density lipoprotein (HDL) cholesterol level and antiatherogenic index. ${ }^{6}$ In addition, ethylene glycol, octreotide and massive doses of ascorbic acid can cause acute oxalate nephropathy. ${ }^{5}$

Bakul et al. reported that the oxalate content of the bilimbi fruit was found to be $25.1 \mathrm{mg} / 100 \mathrm{~g}$ of fruit, thus its oxalate content is nearly five times higher than that of tomato and three times higher than in pineapple. ${ }^{6}$ Galvão et al. found that the oxalic acid content of $A$. bilimbi fruit ranges from 8.57 to $10.32 \mathrm{mg} / 100$ $\mathrm{g}$ of the fruit. The highest levels were seen in half ripe fruit in rainy season. ${ }^{4}$ Thus drinking the juice of the bilimbi fruit is a risk of developing oxalate nephropathy.

Another species called A. Carambola which belongs to the same family has some side effects like muscle weakness, intractable hiccups, mental confusion and seizures. ${ }^{11,12}$ But in this case, the fruit was A. bilimbi as the patient's husband confirmed the species. The high oxalate content of $A$. bilimbi results in the development of oxalate crystals in the kidney. Renal epithelial cells endocytosed the crystals and these crystals cause fibrosis by stimulating specific genes in renal tubular cells. ${ }^{6}$

We faced some problems in diagnosis and therapeutic approaches. Acute oxalate nephropathy due to ingestion of $A$. bilimbi juice is rare. Only three case reports were published on this topic before; two of them are from India and one is from Bangladesh. ${ }^{5,6,13}$ There is lack of scientific literature and a report on this topic. This is only the second case report of acute oxalate nephropathy due to A. bilimbi reported from Bangladesh.

\section{Conclusion}

Although in South East Asian countries A. bilimbi juice is used as a remedy of hypertension, diabetes, and dyslipidemia, taking huge amounts of juice in concentrated form can lead to acute renal failure. Because of that awareness should be created not to take high concentrated oxalate-containing fruits and further scientific investigations on this topic should be performed.

\section{Discussion}

Acute renal failure (ARF) that occurs after ingestion of bilimbi juice is due to the deposition of calcium oxalate crystals within the renal tubules, thus blocking the tubules. In both primary and secondary hyperoxaluria, oxalate nephropathy can occur. In Type 1 primary hyperoxaluria, there is a reduction of alanine glyoxylate aminotransferase activity in the liver. This leads to an accumulation of oxalate. ' Type 2 primary hyperoxaluria occurs due to a mutation of glyoxylatereductase/D-glycerate dehydrogenase. This leads to the urinary excretion of increased amounts of L-glyceric acid and oxalate.? Secondary hyperoxaluria occurs due to increased dietary intake of oxalate, increased 


\section{Case Report}

\section{References}

1. Isnard Bagnis C, Deray G, Baumelou A, Le Quintrec M, Vanherweghem JL. Herbs and the kidney. Am J Kidney Dis. 2004 Jul;44(1):1-11.

2. Jha V, Parameswaran S. Community-acquired acute kidney injury in tropical countries. Nat Rev Nephrol. 2013 May;9(5):278-90.

3. Oommachan M, Khan SS. Plants in aid of family planning programme. Anc Sci Life. 1981 Jul; $1(1): 67-9$.

4. Galvão de Lima VL, de Almeida Mélo E, dos Santos Lima L. Physicochemical characteristics of bilimbi (Averrhoa bilimbi L.). Rev Bras Frutic. 2001 Aug;23(2):421-3.

5. Nair S, George J, Kumar S, Gracious N, Acute oxalate nephropathy following ingestion of Averrhoa bilimbi juice. Case Rep Nephrol. 2014;2014:240936. 6. Bakul G, Unni VN, Seethaleksmy NV, Mathew A, Rajesh R, Kurien G, et al. Acute oxalate nephropathy due to 'Averrhoa bilimbi' fruit juice ingestion. Indian J Nephrol. 2013 Jul;23(4):297-300.

7. Williams HE, Wandzilak TR. Oxalate synthesis, transport and the hyperoxaluric syndromes. J Urol. 1989 Mar;141 (3 Pt 2):742-9.
8. Chlebeck PT, Milliner DS, Smith LH. Long-term prognosis in primary hyperoxaluria type II (L-glyceric aciduria). Am J Kidney Dis. 1994 Feb;23(2):255-9. 9. Janick J, Paull RE. The encyclopedia of fruit and nuts. Wallingford: CABI Publishers; 2008. p. 575

10. Ambili S, Subramoniam A, Nagarajan NS. Studies on the antihyperlipidemic properties of Averrhoa bilimbi fruit in rats. Planta Med. 2009 Jan;75(1):558.

11. Neto MM, da Costa JA, Garcia-Cairasco N, Netto JC, Nakagawa B, Dantas M. Intoxication by star fruit (Averrhoa carambola) in 32 uraemic patients: treatment and outcome. Nephrol Dial Transplant. 2003 Jan;18(1):120-5.

12. Neto MM, Robl F, Netto JC. Intoxication by star fruit (Averrhoa carambola) in six dialysis patients? (Preliminary report). Nephrol Dial Transplant. 1998 Mar;13(3):570-2.

13. Billah MM, Rahman MA, Rahim MA, Swarna AT, Mitra P, Chowdhury TA, et al. Acute kidney injury following ingestion of Averrhoa bilimbi Juice. Bangladesh Crit Care J. 2015 Sep;3(2):71-3.

\section{Acknowledgments}

We are grateful to Dr. Faisol Kabir (Intern Doctor, Dhaka Medical College Hospital, Dhaka, Bangladesh) and Dr. Gourab Adhikary, Research Investigator, International Centre for Diarrhoeal Disease Research, Bangladesh (ICDDR.B) for their guidance and support in writing the manuscript.

\section{Conflict of Interest Statement at Funding}

The author has no funding, financial relationships or conflicts of interest to disclose.

\section{Author Contributions}

Conceptualization, Contribution of patients or study materials, Data collection, Statistical advice, Data analysis and interpretation, Writing: TB. Funding acquisition, Critical revision of the manuscript, Approval of the final version, Administrative/technical advice: SKB.

Cite as:

Gupta RD, Islam M, Datta D, Kumar S. Acute oxalate nephropathy due to bilimbi poisoning: a case report. Int J Med Students. 2016 JanApr;4(1):33-5. 